\title{
SISTEMATIZAÇÃO DO ACERVO BIBLIOGRÁFICO DO MAE RELACIONADO À CERÂMICA PRÉ-HISTÓRICA BRASILEIRA (banco de dados)
}

Este projeto, de nossa autoria, foi desenvolvido junto à Biblioteca do MAE, sob nossa orientação, por dois graduandos em Ciências Sociais da USP, LETICIA DE BARROS MOTTA e WALTER FAGUNDES MORALES, durante o ano de 1991; contou com o financiamento da COSEAS, através da concessão de duas BOLSAS-TRABALHO; objetivou a organizaçāo de um BANCO DE DADOS COMENTADO relacionado às ocupações cerâmicas pré-coloniais brasileiras, com o inventário, classificação e organização de todo o acervo bibliográfico sobre o tema (teorias, metodologias, técnicas de pesquisa, estudo de áreas) em forma de comunicações, artigos, ensaios, monografias e teses.

Para o trabalho elaborou-se um RESUMO sobre cada publicação, com destaque do nome do autor, título da publicação, nủmero da edição, nome da editora, local e ano de publicação, visando seguir o programa de $\mathbf{N}$ FORMATIZAÇĀO DA USP, ou seja, de suas unidades de ensino e pesquisa, do SIBI e da própria Biblioteca do MAE.

Após doze meses ininterruptos de pesquisa, os dois bolsistas finalizaram o primeiro BANCO DE DADOS COMENTADO sobre o acervo bibliográfico do MAE, relacionado à cerâmica pré-histórica brasileira, com registro e sintese de 53 PERIÓDICOS (36 nacionais e 17 estrangeiros), destacando-se 233 TITULOS, 92 LIVROS e 15 TESES (Livre-Docência, Doutorado, Mestrado), que se encontra à disposição do público interessado, na Biblioteca e no Laboratório de Arqueologia do MAE.

Marcia Angelina Alves* 